\title{
The Sensationalist Discourse of Science Diplomacy: A Critical Reflection
}

\author{
Tim Flink \\ German Centre of Higher Education and Science Studies (DZHW) and \\ Humboldt-Universität zu Berlin, Berlin, Germany \\ tim.flink@hu-berlin.de
}

Received: 9 June 2020; revised: 29 June 2020; accepted: 13 July 2020

\section{Summary}

For almost twenty years, the concept of science diplomacy has gained momentum in a public discourse that brings together science policy and international affairs. While some policy actions were newly established and others got into the stride of science diplomacy, the public discourse kept proliferating and has greatly enlarged the concept's meaning. Reviewing one of its most common definitions, this contribution critically reflects on the sensational promises made by advocates and endorsers of science diplomacy. Their framing bears on a popular and romantic image of science that would hold salutary capacities to solve problems no matter how complex and that goes into rhapsodies about scientists as cosmopolitans who would eagerly collaborate with kindred spirits regardless of national and cultural contexts. Apart from the fact that science tends to get instrumentalised for particularistic purposes, these reveries are problematic, as they overbook expectations about science and foreign politics that can hardly be fulfilled.

\section{Keywords}

governance of science - globalisation studies - social studies of science - higher education studies - international relations - discourse analysis - science diplomacy conceptual analysis 


\section{Introduction}

Globalisation with its interrelated flows of people, technologies, ideas, resources and media, ${ }^{1}$ just as well as science cut through almost all aspects of human civilisation. Human circumstances can affect and be affected by global developments and by science, its scrutiny, findings and driving force to advancement that concurrently decreases and increases uncertainties. ${ }^{2}$ But globalisation and science have also been causally interrelated for centuries. In fact, the formation of nation states has co-evolved with the emergence of modern science and higher education: academies and universities were granted exclusive supraregional and supranational rights and became institutional role models proliferating across Europe and beyond. ${ }^{3}$ Scholars and students immediately enjoyed the privileges of crossing territorial borders and exchanging with kindred spirits under the auspices of local, national and imperial patronage in Europe. By the early 18th century, international exchange among scholars was already astonishingly intense. ${ }^{4}$ The crossing of territorial borders was regarded an essential prerequisite of scientific functional differentiation, ${ }^{5}$ as access to hitherto unknown objects of discovery and, most importantly, to communication partners could be ensured.

Political leaders in Europe had initially supported the scientific crossing of borders, especially to seize personal reputation and education, before becoming aware that specific scientific methods and results were also relevant for economic profit and national security. In fact, the 19th century heralded a phase of renationalisation toward its excess in the mid-2oth century, ${ }^{6}$ a period of time that partly hindered knowledge flows across borders.

Whereas most countries (and international organisations) had not even developed dedicated science, technology and innovation (STI) or higher education (HE) policies before the $1950{ }^{\circ},{ }^{7}$ only recently did foreign policy making become aware that STI and HE — and not only security-related technologies 8 - matter to international relations. ${ }^{9}$ While sT I and HE framed a

1 Appadurai 1990, 296-297.

2 Böhme 1997, 26o-262.

3 Rüegg 1996; Krücken, Kosmützky and Torka 2007.

4 Edelstein et al. 2017, 404-409, 413.

5 Numerous examples were provided by historians, for example, Daston 1991; Crawford, Shinn and Sörlin 1993; Rüegg 1996; Stichweh 1996; Edelstein et al. 2017.

6 Dienel, Hammerlund and Peterson 2002, 267-268.

7 For a historical overview of national, transnational and supranational sti policies in Europe, see Flink 2016, 6o-72.

8 Fritsch 2011, 33.

9 Skolnikoff 1993. 
similar awareness by concepts of grand challenges ${ }^{10}$ and excellence, ${ }^{11}$ in foreign policy it was introduced by the concept of science diplomacy.

Science diplomacy emerged as part of a public discourse promulgated during the first years of the millennium by actors from the United States, Europe and a few other states such as Canada, Japan, New Zealand and South Korea. Ever since its rollout, its advocates have claimed that science should be better harnessed to inform foreign policy making, that international sTi collaborations and HE exchange should be better facilitated by diplomatic actions and that science - due to its allegedly non-political nature and universalistic norms - should be employed as a form of ersatz diplomacy, especially when official state relations are rife with tension. ${ }^{12}$ However, a closer look at the conceptual work of its advocating community reveals, as will be reflected on in the next paragraphs, that the public discourse on science diplomacy has been overbooked by sensationalist and affirmative talks its responsible actors can hardly live up to. Second, it illustrates that definitory expansions of science diplomacy will increasingly render the concept indistinctive and normatively dubious.

\section{2 The Sensational Promises of Science Diplomacy}

Activities at the intersection of science policy and international relations have existed for decades: national ministries and agencies as well as international organisations dispatch science attachés, counsellors and liaison officers to take care of bi-lateral and multilateral research and higher education funding programs, to observe related activities abroad, to hedge investment opportunities and to promote products, talent and funding programs from home. ${ }^{13}$ In some national cases, these posts also gather intelligence on security-related STI activities or engage in high-tech espionage and counter-espionage. ${ }^{14}$

Science diplomacy may have denoted these activities, whereas the concept and adjacent terms cannot be found mentioned before the millennium. Searches in the Web of Science, Scopus, Google N-gram and in journal archives, such as Nature and Science, show two entries from 1945 to 2000. In 1974, the journal Science discussed the unfitting position of science and technology

\footnotetext{
$10 \quad$ Flink and Kaldewey 2018, 16-18.

11 Flink and Peter 2018, 440-446.

12 Berkman 2019, 68-69.

13 Flink and Schreiterer 2010; Flink and Rüffin 2019; Ruffini 2017.

14 Lexow 1966; Redden 2019.
} 
in the US State Department (DoS). ${ }^{15}$ And in 1990, the same journal ${ }^{16}$ celebrated the Washington Fellowships funded by the American Association for the Advancement of Science (AAAS), a program that has seconded scientists in the US Congress, the DoS and other executive branches since 1973. Only after the millennium did AAAS members and endorsers start campaigning publicly for science diplomacy, ${ }^{17}$ which can be interpreted as a virtuous reaction to the poor standing of science in US foreign policy. ${ }^{18}$ Anticipating two US presidencies under Democratic Party leadership and backed by a decennial private endowment to the AAAs that founded its Center for Science Diplomacy, windows of opportunity could be opened to market science diplomacy in Washington, DC, as well as abroad. The recent anti-academic attitude of the Donald Trump administration, which has denied scientific evidence, cut federal funds for academic research and pulled back the wheel from smart to hard power with an outright refutation of multilateralism, enraged many academics in the United States who call for science diplomacy a fortiori. This has made the concept look tantamount to calls for greater public engagement in science.

The narrative of science diplomacy bears on the scenario of a world deteriorating by numerous grand challenges of planetary dimension which national governments are unwilling or unable to tackle. In this Dickensian portrait, science diplomacy promises to (re)install collaboration of actors and reason in international affairs. Amidst defective national egoistic policy-making, scientists and their advocates are portrayed as competent and altruistic saviours that help the world's society solve its grand challenges and overcome its looming threats. ${ }^{19}$ The allegedly collaborative attitude of scientific researchers alludes — vaguely and affirmatively as is the entire discourse — to scientific universalism, a central element of Robert K. Merton's Normative Structure of Science: ${ }^{20}$ that scientific claims must be assessed by the scientists irrespective of the particulars of those who are claiming, for example, race, gender, academic status, national provenance. It is important to note that scientific universalism is supposed to guide the internal social relations of the science system, and — as trivial as it may sound — that we are dealing with an ought-to norm. However, the discourse on science diplomacy feigns scientific

\footnotetext{
15 Walsh 1974. This observation matches with a Central Intelligence Agency (CIA) report assessing the US science attaché program; see Lexow 1966.

16 Science 1990.

17 Forde 2004; Lord and Turekian 2007; Fedoroff 2009.

18 Flink and Schreiterer 2010, 674-675.

19 Fedoroff 2009; Turekian et al. 2015.

20 Merton 1973, 270-273.
} 
universalism into a version of cosmopolitanism, and pretends that both would de facto constitute the inner life of scientists; that is, those alleged august men that would but only work in a collaborative manner, sharing knowledge and accepting to value truth claims regardless wherefrom. Moreover and according to this discourse, scientists would be brilliant in transferring their knowledge to avert egoistic, uninformed and irrevocably detrimental decisions made by politicians. ${ }^{21}$ Whether it is a rhetoric strategy, a firm conviction or both, these claims allow for devaluating national politics for having egoistic interests, which would need to be surmounted if cross-border challenges were to be tackled. Correspondingly, the imagined figure of a traditional diplomat is often implicitly used to substantiate that foreign policy making was incapable of grasping complex issues and overcoming national interests. Kristin Lord and Vaughan Turekian, promoters of science diplomacy, even argued that scientists were better diplomats and should 'maybe even take the lead' in diplomacy. ${ }^{22}$ Apart from these sensationalist promises, it is the alleged unpolitical nature of science that gets instrumentalised for political purposes.

The only problem is that such an idealised image of science hardly matches with lifeworld realities, and it does not even need 50 years of the Social Studies of Science to continuously prove that science - just as any other social system - may also contain chauvinism, fierce competition, vanity and reputation games, misconduct and unsavoury entanglements with nefarious business and political interests. To provide only a few examples with regard to its international dimensions, editors of the scientific journal Nature ${ }^{23}$ recently criticised that researchers and especially reviewers would have increasingly devalued the works of 'others' on the basis of national-cultural stereotypes. ${ }^{24}$ The US Department of Health's Office for Research Integrity (ORI) even openly accuses and warns against practices of plagiarism that would be common among young scientists from 'non-Western cultures' (i.e., Central and Eastern European, Latin American, Middle Eastern and Southeast Asian). ${ }^{25}$ But also international scientific engagement under the heading of science diplomacy was held ethically problematic, as it also led to parachute science. ${ }^{26}$

That large parts of the discourse on science diplomacy sensationally portrays scientists as unpolitical, cosmopolitan and truth-seeking collaborators,

\footnotetext{
21 Science advice for policy is far more complex than envisioned in the discourse on science diplomacy; see Collingridge and Reeve 1986; Pielke 2007.

22 Lord and Turekian 2007, 770.

23 'Judge Science on Merit, Not Assumptions' 2016.

24 For a recent confirmation of this social technique of othering, see Hesselmann 2019.

25 Roig 2015.

26 Smith 2014.
} 
however, seems not naive but strategic. And yet, the question is whether such raised expectations, as provided by promoters of this discourse, are not greatly overdrawn - and what happens, if they get disappointed?

\section{3}

\section{A Strategic Definition of Science Diplomacy}

The proliferation of science diplomacy came along with attempts at defining and demarcating the concept. Many actors in the field refer to a threefold definition produced in 2010 by the Royal Society's publication New Frontiers in Science Diplomacy. ${ }^{27}$ The definition, as many call it, offers an entire bundle of three means-to-ends conjunctions of the terms science and diplomacy: 1) science in diplomacy refers to scientific evidence and expertise that informs foreign policy making, 2) diplomacy for science describes diplomatic activities that foster international academic collaborations and 3) science for diplomacy means that international science collaborations get used as a form of ersatz diplomacy (i.e., to influence the relations between states). Obviously, this socalled definition, concocted by a small number of practitioners and advocates from an Anglo-American context, holds little value for scholarly analytical purposes, as it offers only a few ostensive examples that may - or may not - be representative of an entire intersection of two social realms, each of which is complex enough by itself. Strikingly, for a discourse that vividly plays on the image of 'scientificness', its definition — some even call it a taxonomy — does not even pass muster with definitory requirements.

Definitions should obviate ambiguity, and usually their essential components get clearly defined alongside, unless they are trivial or common sense. But neither science nor diplomacy can bear on common understandings. If only we take the subject of this so-called definition (i.e., diplomacy), we can associate so many things with it that listing them would go far beyond the scope of this essay or even a book. For example, diplomacy might refer to specific actions, to professionals in public service, to a style of communication (e.g., a noncommittal consenting language) and to social habits that follow a specific choreography. ${ }^{28}$ A traditional understanding would see diplomacy confined to activities and institutions of states, acknowledging extraterritorial sovereignty and international interests to each other via immaterial and material things: titles and other courtesy rules, treaties, embassies, permanent representations,

\footnotetext{
27 Royal Society 2010, 5-12.

28 Jönsson 2016, 84 .
} 
organisations and so on. Recent studies have turned to sociological perspectives recognising that any social subject can seize diplomatic 'actorhood', as soon as it becomes relevant in international communication flows. ${ }^{29}$ In this respect, it is conspicuous that on the outset of their agenda setting, advocates of science diplomacy emphasised their novel reform approach and impact on the diplomatic world, whereas that very world had already been subject to strong conversion and reform processes since the beginning of the 1990s. ${ }^{30}$ Now, after almost twenty years of discourse, science diplomacy advocates are resorting to another framing technique; that is, they are increasingly using historical examples to illustrate the legacy of science diplomacy, as if it was always there but never recognised.

Last but not least, with the tripartite nature of the definition, actors can easily mark their relevance in a circular way. The best analogy is a Droste effect we know from art; that is, when a picture keeps reappearing within itself. In this vein, science diplomacy is often used to argue, for example, that science changes foreign policy, which then supports science, which again helps foreign policy and so forth. For seizing self-legitimacy and extending communication acts to further target groups, this rhetorical strategy can hardly be refuted by endorsers of STI, HE and foreign policy.

And yet, there are several drawbacks to this non-negatable pseudo-definition. First, science not only provides solutions and certainties, but its findings also create negative externalities and uncertainties, as generations of science, technology and innovation scholars have illustrated. ${ }^{31}$ While an entire transdisciplinary field of socio-scientific risk assessment is being ignored by advocates of science diplomacy, they must position their concept to these challenges, particularly because decision-making in international relations cannot, as has been recognised, resort to political authority known from domestic settings. Second, are we not dealing with an oxymoron when diplomacy for science is stipulated in the same breath with science for diplomacy? Because so far the discourse holds that diplomacy should foster international collaborations of scientists to support their (allegedly) non-political interests of advancing knowledge, while at the same time its advocates want to instrumentalise scientists for political purposes. But is it acceptable for a scientist to hear that

\footnotetext{
29 For many, see Murray et al. 2011; Adler-Nissen 2015.

$30 \quad$ Murray et al. 2011; Constantinou, Kerr and Sharp 2016.

$31 \quad$ Funtowicz and Ravetz 1993; Sarewitz 1996.
} 
he or she would be an ideal asset for political purposes?32 During a high-level round table on science diplomacy in 2019, featured by the German Academic Exchange Service, a representative from a foreign ministry argued that using science collaborations for communicating especially with autocratic regimes was most wanted: on one hand, for the (realist) sake of keeping wires into such problematic foreign countries, and on the other hand to support their academic civil societies. The representative argued that one should also think in longer terms, i.e. in expectation of regime changes, which might enhance scientists of a foreign country to seize elite political positions, after which they certainly would remember with whom they had enjoyed collaborating. This line of argumentation is comprehensible, and yet large parts of the audience seemed sceptical because scientists in autocratic states can be equally supportive of their political elites or be endangered because of their international collaborations, which is dubious to speculate about.

\section{$4 \quad$ Conclusion}

The discourse on science diplomacy has been an eye-opener for many actors - diplomats, as well as policy-makers in different departments, STI and HE program managers and maybe even some active or former scientists. With its narrative of imminence and looming threats that call for responses and underpin the importance of activities at the intersection of science, higher education and international relations, advocates of science diplomacy have enjoyed a long phase of agenda setting and self-legitimisation. Thereby, the concept has been easy to promote, as it latches on to many other concepts ${ }^{33}$ which are equally embedded in affirmative discourses of public engagement, such as grand societal challenges, responsible research and innovation, transformative innovation, missions or anything that carries the buzzword 'sustainability'. As international fixtures, these affirmative concepts travel contexts effortlessly because actors, no matter from what functional system, can hardly negate their relevance. It does not make sense to call for the tackling of small

\footnotetext{
32 Obviously, some scientists do not want to be framed as 'science diplomats', especially not when their governments could not offer funding in the first place so that they had to leave the country; see Moro-Martín 2017.

Bensaude-Vincent 2014.
} 
challenges, to do irresponsible research or to vouch for uninformed diplomacy or crude manners in international affairs. ${ }^{34}$

Still, it is surprising not to find any significant opposition or (self-)critical voices that challenge the good-naturedness of science diplomacy, which seems foul in a double sense: on one hand, it is not clear how science diplomacy can be beneficial for science if the latter gets instrumentalised by foreign policy. On the other hand, it is unclear how foreign policy can benefit from science diplomacy, if a romantic image of science is taken for real.

One of the most essential features of science is its social capability of continuous self-correction. If the discourse on science diplomacy has any scientific fundament, its advocates will need to start asking themselves where their affirmative talks and historical fairy tales of heroic actions will lead to.

\section{Bibliography}

'AAAS Washington Fellowships Place Scientists, Engineers in Year-Long Assignments on Science, Diplomacy, and Security'. Science 250 (4981) (1990), 698.

Adler-Nissen, Rebecca. 'Relationalism or Why Diplomats Find International Relations Theory Strange'. In Diplomacy and the Making of World Politics, eds. Ole Jacob Sending, Vincent Pouliot and Iver B. Neumann (Cambridge: Cambridge University Press, 2015), 284-308.

Appadurai, Arjun. 'Disjuncture and Difference in the Global Cultural Economy'. Theory, Culture and Society 7 (2) (1990), 295-310.

Bensaude-Vincent, Bernadette. 'The Politics of Buzzwords at the Interface of Technoscience, Market and Society: The Case of "Public Engagement in Science". Public Understanding of Science 23 (3) (2014), 238-255.

Berkman, Paul Arthur. 'Evolution of Science Diplomacy and Its Local-Global Applications'. European Foreign Affairs Review 24 (2) (2019), 63-79.

Böhme, Gernot. 'The Structures and Prospects of Knowledge Society'. Social Science Information 36 (3) (1997), 447-468.

Collingridge, David and Colin Reeve. Science Speaks to Power: The Role of Experts in Policy Making (New York: St. Martin's Press, 1986).

Constantinou, Costas M., Pauline Kerr and Paul Sharp, eds. The SAGE Handbook of Diplomacy (London: SAGE, 2016).

Crawford, Elisabeth, Terry Shinn and Sverker Sörlin, eds. Denationalizing Science: The Context of International Scientific Practice (Dordrecht: Kluwer Academic, 1993). 
Daston, Lorraine. 'The Ideal and Reality of the Republic of Letters in the Enlightenment'. Science in Context 4 (2) (1991), 367-386.

Dienel, Hans-Luidger, K.G. Hammerlund and Martin Peterson. 'The Historical Context of the Evolution of National Research Systems and International RTD Collaboration'. Innovation: The European Journal of Social Science Research 15 (4) (2002), 265-278.

Edelstein, Dan, Paula Findlen, Giovanna Ceserani, Caroline Winterer and Nicole Coleman. 'Historical Research in a Digital Age: Reflections from the Mapping the Republic of Letters Project'. American Historical Review 122 (2) (2017), 400-424.

Fedoroff, Nina. 'Science Diplomacy in the 21st Century'. Cell 136 (1) (2009), 9-11.

Flink, Tim. Die Entstehung Des Europäischen Forschungsrates: Marktimperative, Geostrategie, Frontier Research (Weilerswist: Velbrück Wissenschaft, 2016).

Flink, Tim and David Kaldewey. 'The New Production of Legitimacy: STI Policy Discourses beyond the Contract Metaphor'. Research Policy 47 (1) (2018), 14-22.

Flink, Tim, and Tobias Peter. 'Excellence and Frontier Research as Travelling Concepts in Science Policymaking'. Minerva 56 (4) (2018), 431-452.

Flink, Tim and Nicolas Rüffin. 'The Current State of the Art of Science Diplomacy'. In Handbook on Science and Public Policy, eds. Dagmar Simon, Stefan Kuhlmann, Weert Canzler and Julia Stamm (Cheltenham: Edward Elgar, 2019), 104-121.

Flink, Tim and Ulrich Schreiterer. 'Science Diplomacy at the Intersection of S\&T Policies and Foreign Affairs: Toward a Typology of National Approaches'. Science and Public Policy 37 (9) (2010), 665-677.

Forde, Anne. 'Strengthening Relationships: The Role of Science in Internationalism and Diplomacy'. Science 4 (July 2004). http://www.sciencemag.org/careers/2004/o6/ strengthening-relationships-role-science-internationalism-and-diplomacy.

Fritsch, Stefan. 'Technology and Global Affairs'. International Studies Perspectives 12 (1) (2011), 27-45.

Funtowicz, Silvio O. and John R. Ravetz. 'Science for the Post-Normal Age'. Futures 25 (7) (1993), 739-755.

Hesselmann, Felicitas. 'Science and Its Others: Examining the Discourse about Scientific Misconduct through a Postcolonial Lens'. Identities 26 (4) (2019), 393-411.

Jönsson, Christer. 'Diplomacy, Communication and Signaling'. In The SAGE Handbook of Diplomacy, eds. Costas M. Constantinou, Pauline Kerr and Paul Sharp (London: SAGE, 2016), 79-91.

'Judge Science on Merit, Not Assumptions'. Editorial. Nature 539 (7628) (2016), 139-140. Krücken, Georg, Anna Kosmützky and Marc Torka. Towards a Multiversity? Universities between Global Trends and National Traditions (Bielefeld: transcript, 2007).

Lexow, Wilton. 'The Science Attache Program'. CIA Studies in Intelligence: A Collection of Articles on the Historical, Operational, Doctrinal, and Theoretical Aspects of Intelligence 10 (1966), 21-27. 
Lord, Kristin M. and Vaughan C. Turekian. 'Time for a New Era of Science Diplomacy'. Science 315 (5813) (2007), 769-770.

Merton, Robert K. 'The Normative Structure of Science'. In The Sociology of Science: Theoretical and Empirical Investigations, eds. Robert K. Merton and Norman W. Storer (Chicago: University of Chicago Press, 1973), 267-278.

Moro-Martín, Amaya. 'How Dare You Call Us Diplomats'. Nature News 543 (7645) (2017), 289.

Murray, Stuart, Paul Sharp, Geoffrey Wiseman, David Criekemans and Jan Melissen. 'The Present and Future of Diplomacy and Diplomatic Studies'. International Studies Review 13 (4) (2011), 709-728.

Pielke, Roger A. The Honest Broker: Making Sense of Science in Policy and Politics (Cambridge: Cambridge University Press, 2007).

Redden, Elisabeth. 'Bills Target Academic Espionage'. Inside Higher Education, 19 June 2019. https://www.insidehighered.com/news/2019/o6/19/two-new-bills-take -different-approach-protecting-us-research-foreign-threats.

Roig, Miguel. Avoiding Plagiarism, Self-Plagiarism, and Other Questionable Writing Practices: A Guide to Ethical Writing (Washington, DC: Office for Research Integrity, US Department of Health and Human Services, 2015). https://ori.hhs.gov/sites/ default/files/plagiarism.pdf.

Royal Society. New Frontiers in Science Diplomacy: Navigating the Changing Balance of Power. January 2010. https://royalsociety.org/ /media/Royal_Society_Content/ policy/publications/2010/4294969468.pdf.

Rüegg, Walter. History of the University in Europe, vol. 2: Universities in the Early Modern Europe (1500-1800) (Cambridge: Cambridge University Press, 1996).

Ruffini, Pierre-Bruno. Science and Diplomacy. A New Dimension of International Relations. (Dordrecht: Springer, 2017).

Sarewitz, Daniel. Frontiers of Illusion: Science, Technology, and the Politics of Progress (Philadelphia, PA: Temple University Press, 1996).

Skolnikoff, Eugene B. The Elusive Transformation: Science, Technology, and the Evolution of International Politics (Princeton: Princeton University Press, 1993).

Smith, Frank L., III. 'Advancing Science Diplomacy: Indonesia and the US Naval Medical Research Unit'. Social Studies of Science 44 (6) (2014), 825-847.

Stichweh, Rudolf. 'Science in the System of World Society'. Social Science Information 35 (2) (1996), 327-340.

Turekian, Vaughan Sarah Macindoe, Daryl Copeland, Lloyd S. Davis, Robert G. Patnam and Maria Pozza. 'The Emergence of Science Diplomacy'. In Science Diplomacy: New Day or False Dawn? eds. Lloyd S. Davis and Robert G. Patman (London: World Scientific, 2015), 3-25.

Walsh, John. 'Putting It Together for Science at the State Department'. Science 185 (4155) (1974), 924. 
Tim Flink

with broad interests and expertise in science, technology and innovation policy, international relations and European governance, and the social studies of science, works as a Postdoctoral Researcher and Lecturer at HumboldtUniversität zu Berlin, and as a Lead Scientist at the German Centre for Higher Education Research and Science Studies. Before starting his career as a researcher, he worked as the Directors' Assistant of the European Liaison Office of the German Research Organisations in Brussels (2006-2007) on various issues of European research policy. 